\title{
RAMULARIA LEAF SPOT EFFECT ON YIELD AND FIBER QUALITY OF COTTON SUBMITTED TO FUNGICIDE APPLICATION ${ }^{1}$
}

\author{
NÉDIO RODRIGO TORMEN ${ }^{2 *}$, LUIZ EDUARDO BASSAY BLUM $^{3}$
}

\begin{abstract}
Ramularia leaf spot (RLS) is the major cotton disease in Brazil and one of the main causes of crop yield reduction. The disease causes defoliation, reduces photosynthetic capacity and causes premature opening of bolls. Due to the impact of RLS on the production of Brazilian cotton and the lack of scientific publications investigating the disease, the present work aims to evaluate the efficiency of fungicides in controlling disease and their impact on yield and fiber quality. Three field experiments were carried out during the 2014/2015 and 2016/2017 seasons in Planaltina, Federal District and Cristalina, Goiás. Experiments followed a randomized complete block design ( 4 blocks) and treatments consisted of the application of fungicides, plus a non-treated plot. The fungicide applications began preventively and were repeated every 14 days until six sprays had been completed. Severity of RLS was assessed and used to calculate the area under disease progress curve (AUDPC). Yield and cotton fiber quality were also evaluated. All fungicides had reduced AUDPC and obtained higher cotton yields in relation to the non-treated plot. Strobilurin-group fungicides (azoxystrobin, pyraclostrobin and picoxystrobin) showed low effectiveness when sprayed alone. The demethylation inhibitor fungicides (difenoconazole, epoxiconazol, tetraconazol and metconazole) were more effective than the strobilurins. The highest efficiency rates were achieved by application of pyraclostrobin + fluxapyroxad, pyraclostrobin + epoxiconazole + fluxapyroxad and fentin hydroxide. Disease severity affected cotton yield, causing losses from $14.8 \%$ to $31.7 \%$. Resultant reductions in cotton fiber quality negatively affect the micronaire composition, altering the length, strength and uniformity of fibers.
\end{abstract}

Keywords: Cotton. Disease control. Ramulariopsis gossypii. Fiber quality. Damage.

\section{MANCHA DE RAMULÁRIA AFETA A PRODUTIVIDADE E QUALIDADE DA FIBRA EM ALGODOEIRO SUBMETIDO À APLICAÇÃO DE FUNGICIDAS}

\begin{abstract}
RESUMO - A mancha de ramulária (MR) é a principal doença do algodoeiro no Brasil e uma das principais causas de redução na produtividade da cultura. A doença causa desfolha, reduz a capacidade fotossintética e provoca abertura precoce de capulhos. Devido a importância da doença para o algodão e da carência de publicações nessa área, neste se avaliou a eficiência de fungicidas no controle da MR em algodoeiro e mensurou os danos causados sobre a produtividade e a qualidade da fibra. Foram conduzidos três experimentos de nas safras 2014/15 e 2016/17, em Planaltina/DF e Cristalina/GO, seguindo o delineamento de blocos casualizados e os tratamentos foram compostos pelos fungicidas, além de uma testemunha. As aplicações foram iniciadas preventivamente e repetidas a cada 14 dias (6 pulverizações). As variáveis mensuradas foram a severidade da MR, com a qual foi calculada a área abaixo da curva de progresso da MR (AACPR), a produtividade e a qualidade da fibra do algodão. Os fungicidas avaliados reduziram significativamente a AACPR em relação à testemunha e obtiveram maior produtividade de algodão em caroço. As estrobilurinas (azoxistrobina, piraclostrobina e picoxistrobina) mostraram baixa efetividade no controle da doença. Os triazóis (difenoconazol, epoxiconazol, tetraconazol e metconazol) apresentaram desempenho superior às estrobilurinas. Maior eficiência de controle foi obtida pela aplicação de piraclostrobina + fluxapiroxade, piraclostrobina + epoxiconazol + fluxapiroxade e hidróxido de fentina. A MR reduziu a produtividade do algodoeiro e induziu danos de 14,8 a $31,7 \%$, reduzindo a qualidade da fibra, impactando negativamente o micronaire, comprimento, resistência e uniformidade da fibra.
\end{abstract}

Palavras-chaves: Algodão. Controle de doenças. Ramulariopsis gossypii. Qualidade da fibra. Danos.

\footnotetext{
${ }^{*}$ Corresponding author

${ }^{1}$ Received for publication in $03 / 01 / 2018$; accepted in $04 / 10 / 2019$.

Paper extracted from the doctoral thesis of the first author.

${ }^{2}$ Department of Research, Instituto Phytus, Planaltina, DF, Brazil; nedio.tormen@iphytus.com - ORCID: 0000-0002-1905-4901.

${ }^{3}$ Department of Plant Pathology, Universidade de Brasília, Brasília, DF, Brazil; luizblum@unb.br - ORCID: 0000-0002-3968-6615.
} 


\section{INTRODUCTION}

Ramularia leaf spot (RLS) is a devastating disease of cotton caused by the fungus Ramulariopsis gossypii (Speg.) U. Braun (sin. = Ramularia areola GF Atk) and its sexual form (Mycosphaerella areola Ehrlich \& FA Wolf) was reported in Brazil in 2016 (MEHTA et al., 2016). Disease presents at the end of the cotton cycle and was considered of only secondary importance until the 90's. However, with the increase of area cultivated in the Midwest and the increased use of susceptible cultivars, it now occurs earlier and it is currently considered the main cotton disease in Brazil (SUASSUNA et al., 2008).

The disease causes early defoliation and consequently reduces the photosynthetic capacity of infected plants. Therefore, yield and fiber quality are compromised. Reductions in yield vary depending on the cultivar used, infection time and disease severity. Damages ranging from 30 to $75 \%$ can occur in Brazil due to the RLS (SUASSUNA et al., 2008; NOVAES et al., 2011; ZANDONÁ et al., 2012).

The infection derives from spores produced on cotton cultural remains consisting of the primary inoculum. The disease is favored by the alternation between wet periods (nocturnal) and dry periods (diurnal), temperatures between $25^{\circ} \mathrm{C}$ and $30^{\circ} \mathrm{C}$ and relative humidity above $80 \%$ (RATHAIAH, 1977; PAIVA, 2001; IAMAMOTO, 2003). The above conditions occur very frequently in the Brazilian Cerrado region, especially after the closure of the cotton lines (SUASSUNA et al., 2008).

RLS can be controlled through crop rotation, balanced fertilization, genetic resistance, controlling seeding season, cultural management and fungicide application (CHITARRA et al., 2005; ROCHA; CARVALHO; OLIVEIRA, 2005; SUASSUNA et al., 2008). Genetic resistance is the most economical and efficient form of control, however, most cultivars currently used present medium to high susceptibility to the disease (CIA et al., 2009).

Consequently, fungicides are the predominant RLS control practice in Brazil (SUASSUNA; COUTINHO, 2007; AQUINO et al., 2008). On average, seven applications of fungicides are carried out during the cotton cycle, of which more than $90 \%$ are used to control RLS (KLEFFMANN, 2015). The continuous use of fungicides and the genetic variability of $R$. gossypii pose a significant risk for selection of resistant fungus populations to fungicide. There is a great concern about the possibility of resistant population selection and the consequent loss of fungicide effectiveness (ISHII; HOLLOMONN, 2015). Isolates of $R$. gossypii with low sensitivity to the Quinone Outside Inhibitors (QoI) group of fungicides have been already identified (FRAC, 2012).
Use of controlled RLS handling practices are essential for the cotton production chain sustainability in Brazil. Fungicides, as important tools in the integrated handling, should be used in a rational way. To maximize the benefits of fungicides, knowledge about efficiency of active ingredients and characteristics of chemical fungicide groups available in the Brazilian market is indispensable. Identification of more efficient fungicides is one of the first steps in constructing an integrated disease management program that prioritizes, in addition to efficient RLS control, minimizing fungicide application. The situation above could lead to reductions in environmental contamination and reduce the selective pressure for resistance on $R$. gossypii populations, increasing the fungicides useful life and reducing control costs.

Despite the importance of the disease in Brazil, there are few scientific publications describing the effects of the chemical control of the disease. Therefore, the present work has the objective of evaluating fungicide efficiency in controlling RLS infection of cotton leaves, measuring damages to crop yield and evaluating effects on cotton fiber quality.

\section{MATERIAL AND METHODS}

Three field experiments were conducted in the Planaltina, Federal District (Planaltina DF) 2014 -2015 crop (latitude 15³9'55.7"S, longitude $47^{\circ}$ 19'51.4"W and $868 \mathrm{~m}$ altitude), Cristalina, Goiás (Cristalina GO) 2014-2015 crop (16²'37.7"S, $47^{\circ} 37^{\prime} 50,4^{\prime \prime} \mathrm{W}, 1009 \mathrm{~m}$ altitude) and Planaltina DF 2016-2017 crop (1540'01.8"S, 47²0'03.7"W,874 $\mathrm{m}$ altitude). These experiments will henceforth be referred to as Planaltina/2015, Cristalina/2015 and Planaltina/2017.

Soil from the experiment site (Table 1) located in Planaltina DF was classified as Oxisol and is composed of $491 \mathrm{~g} \mathrm{~kg}^{-1}$ clay, $300 \mathrm{~g} \mathrm{~kg}^{-1}$ silt and $209 \mathrm{~g} \mathrm{~kg}^{-1}$ sand in the 2015 experiment and $488 \mathrm{~g} \mathrm{~kg}^{-1}$ clay, $305 \mathrm{~g} \mathrm{~kg}^{-1}$ silt and $207 \mathrm{~g} \mathrm{~kg}^{-1}$ sand in the 2017 experiment. The experiment site soil in Cristalina GO was classified as Oxisol and is composed of $762 \mathrm{~g} \mathrm{~kg}^{-1}$ clay, $187 \mathrm{~g} \mathrm{~kg}^{-1}$ silt and $51 \mathrm{~g}$ $\mathrm{kg}^{-1}$ sand.

Meteorological data (Figure 1) were collected from automatic meteorological stations located at a distance of less than $1,000 \mathrm{~m}$ from each experiment. The accumulated rainfall along the cotton crop cycle was $900.9 \mathrm{~mm}$ in Planaltina/2015, $701.6 \mathrm{~mm}$ in Cristalina/2015 and $688.4 \mathrm{~mm}$ in Planaltina/2017. The mean temperatures recorded in these experiments were $22.3, \quad 18.0$ and $22.7^{\circ} \mathrm{C}$, respectively. 
Table 1. Chemical properties of the soil in Planaltina 2015-2017 and in Cristalina 2015, ramularia leaf spot chemical control experiment areas.

\begin{tabular}{|c|c|c|c|c|c|c|c|c|c|c|c|}
\hline \multirow{2}{*}{ Site/Year } & $\mathrm{pH}$ & $\mathrm{Al}^{3+}$ & $\mathrm{Ca}^{2+}$ & $\mathrm{Mg}^{2+}$ & $\mathrm{K}^{+}$ & $\mathrm{CEC}$ & $\mathrm{m}$ & $\mathrm{V}$ & S.O.M. & $\mathrm{S}-\mathrm{SO}_{4}{ }^{2-}$ & $\mathrm{P}$ \\
\hline & & \multicolumn{5}{|c|}{ - } & \multicolumn{2}{|c|}{------ \% ------ } & $\mathrm{g} \mathrm{kg}^{-1}$ & \multicolumn{2}{|c|}{----- $\mathrm{mg} \mathrm{dm}^{-3}$} \\
\hline Planaltina/2015 & 6.00 & 0.01 & 5.83 & 1.84 & 0.65 & 11.80 & 0.10 & 70.50 & 35 & 9.00 & 24.15 \\
\hline Cristalina/2015 & 5.30 & 0.00 & 2.40 & 0.90 & 0.22 & 6.12 & 0.00 & 57.52 & 34 & 26.00 & 5.40 \\
\hline Planaltina/2017 & 5.70 & 0.01 & 3.74 & 1.14 & 0.74 & 9.10 & 0.20 & 61.80 & 36 & 11.00 & 21.69 \\
\hline
\end{tabular}

$\mathrm{m}$ - aluminum saturation; V - base saturation; S.O.M. - soil organic matter; C.E.C. - cation exchange capacity.

The climate where the experiments were performed is characterized as tropical with a defined dry season. It has an annual rainfall of $1446 \mathrm{~mm}$, which is concentrated in the months of October to May. Annual average temperatures (Figure 1) were $28.6^{\circ} \mathrm{C}$ (maximum) and $16.8^{\circ} \mathrm{C}$ (minimum). The two sites have been exploited by agriculture and livestock for more than 20 years and are currently operating under a no-tillage system to produce soybeans, corn, beans and cotton. Three experiments were installed in areas where cotton had not been cultivated in the previous crop, but had been in the past, at which time RLS occurrence in the area was verified.
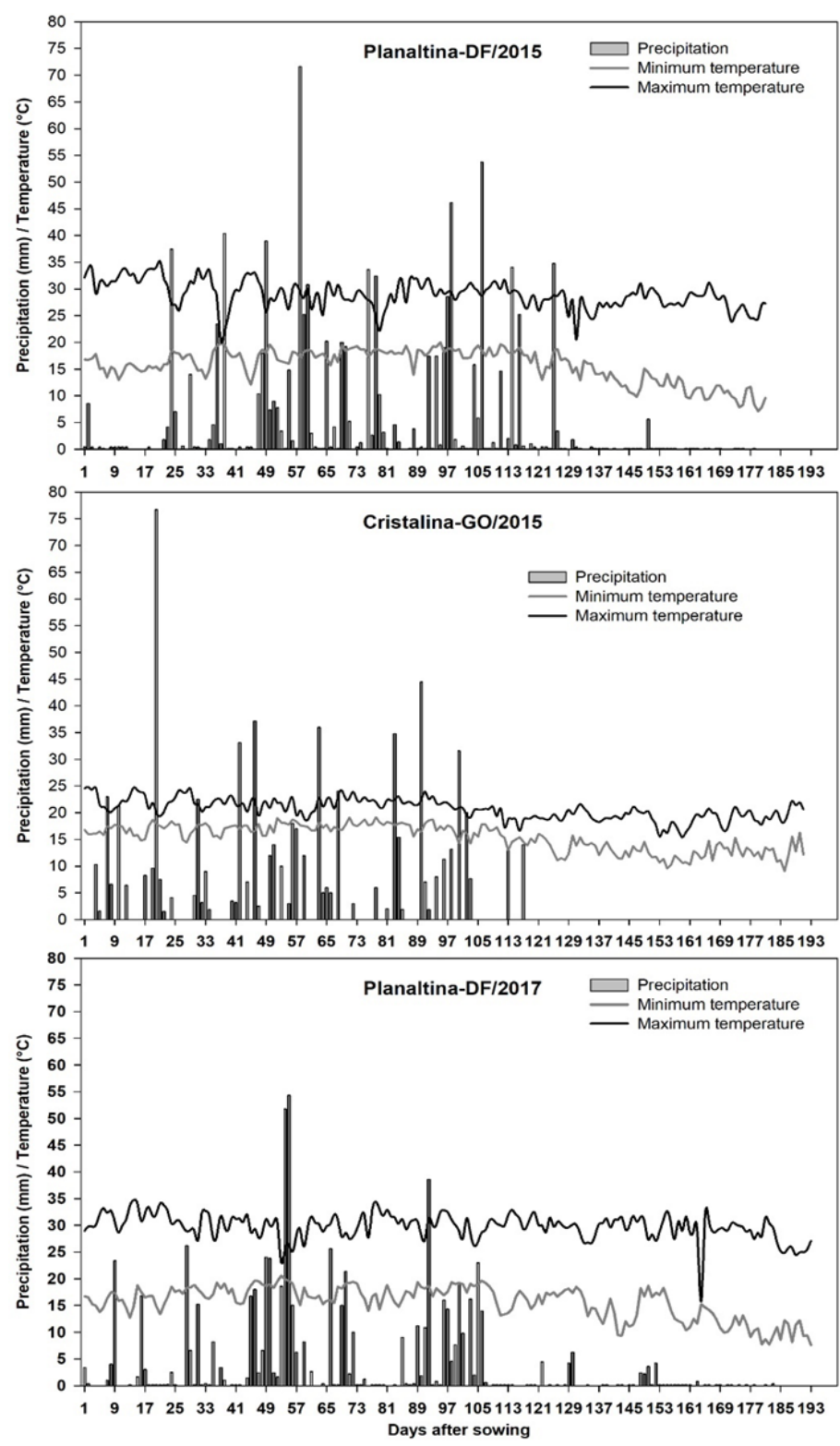

Figure 1. Environmental conditions (precipitation, minimum and maximum temperature) in the ramularia leaf spot chemical control experiments conducted in Planaltina/2015, Cristalina/2015 and Planaltina/2017. 
Seeding was carried out in early January, using cotton cultivars BRS 293, BRS 336RF and FM 983GLT for the Planaltina/2015, Cristalina/2015 and Planaltina/2017 areas, respectively. A Stara SHM 1113 seeder was used in the Planaltina experiment and a John Deere DB40 seeder in the Cristalina experiment. Row spacing was $0.76 \mathrm{~m}$, with 8 seeds $\mathrm{m}^{-1}\left(\sim 104,000\right.$ plants $\left.\mathrm{ha}^{-1}\right)$. The crop handling practices, including fertilization, weed management, pest management and use of growth regulator were performed according to Beltrão et al. (2008).
The experiments were installed following a randomized complete block design with four replicates. The experimental plots were composed of four cotton rows and five meters long $(3.04 \mathrm{~m} \mathrm{x} 5$ $\mathrm{m})$, with a total area of $15.2 \mathrm{~m}^{2}$. Useful area of each experimental plot was composed of two central rows and four meters long, excluding $0.5 \mathrm{~m}$ from the ends of each plot as a border, resulting in a total area of $6.08 \mathrm{~m}^{2}$. The experiment was installed three times, with each site being considered a repeat, and the treatments applied are described in Table 2.

Table 2. Active ingredient, commercial products, and fungicide doses used in Planaltina DF and Cristalina GO cotton crop experiments to control ramularia leaf spot during the 2014-2015 and 2016-2017 seasons.

\begin{tabular}{|c|c|c|c|c|}
\hline Active ingredient & Commercial product & g.a.i. $\mathrm{kg}^{-1}$ & $\begin{array}{c}\text { p.c. } \\
m L \mathrm{ha}^{-1}\end{array}$ & $\begin{array}{l}\text { g.a.i. } \\
\text { g ha }^{-1}\end{array}$ \\
\hline Non-treated & - & - & - & - \\
\hline Azoxystrobin & Priori & 250 & 280 & 70 \\
\hline Picoxystrobin & Oranis & 500 & 250 & 125 \\
\hline Pyraclostrobin & Comet & 250 & 400 & 100 \\
\hline Difenoconazole & Score & 250 & 180 & 45 \\
\hline Epoxiconazole & Soprano $125 \mathrm{SC}$ & 125 & 400 & 50 \\
\hline Tetraconazole & Eminent & 125 & 450 & 56.25 \\
\hline Metconazole & Caramba & 90 & 900 & 81 \\
\hline azoxystrobin + difenoconazole & Amistar Top & $200+125$ & 350 & $70+43.75$ \\
\hline azoxystrobin + tetraconazole & Domark Excell & $100+80$ & 700 & $70+56$ \\
\hline pyraclostrobin + metconazole & Opera Ultra & $130+80$ & 770 & $100+61.6$ \\
\hline trifloxystrobin + prothioconazole & Fox & $150+175$ & 400 & $60+70$ \\
\hline azoxystrobin + benzovindiflupyr & Elatus & $300+150$ & 230 & $69+34.5$ \\
\hline pyraclostrobin + fluxapyroxad & Orkestra SC & $333+167$ & 300 & $99.9+50.1$ \\
\hline $\begin{array}{l}\text { pyraclostrobin }+ \text { epoxiconazole }+ \\
\text { fluxapiroxad }\end{array}$ & Ativum EC & $81+50+50$ & 800 & $64.8+40+40$ \\
\hline $\begin{array}{c}\text { trifloxystrobin }+ \text { prothioconazole }+ \\
\text { bixafem }\end{array}$ & Fox Xpro & $150+175+125$ & 400 & $60+70+50$ \\
\hline fentin hydroxide & Mertin 400 & 400 & 700 & 280 \\
\hline
\end{tabular}

Six applications of each treatment (Table 3) were performed throughout the crop cycle, starting preventively and reapplying every 14 days. The fungicide application was carried out with a constant pressure $\left(\mathrm{CO}_{2}\right)$ equipment, equipped with a six nozzles (Teejet XR11002) boom sprayer. The spray volume was calibrated to $150 \mathrm{~L} \mathrm{ha}^{-1}$. The working pressure was constant $(270 \mathrm{kPa})$ and spray volume adjustment was achieved due to the application speed. 
N. R. TORMEN et al.

Table 3. Date, stage and meteorological conditions recorded at the time of fungicide application in Planaltina/2015, Cristalina/2015 and Planaltina/2017.

\begin{tabular}{|c|c|c|c|c|c|c|c|}
\hline Application & Date & $\begin{array}{c}\text { Growth } \\
\text { stage } \\
\text { (days) } \\
\end{array}$ & Phenology & $\begin{array}{c}\text { Temperature } \\
\left({ }^{\circ} \mathrm{C}\right)\end{array}$ & $\begin{array}{c}\text { Relative } \\
\text { humidity (\%) }\end{array}$ & Wind speed $\left(\mathrm{km} \mathrm{h}^{-1}\right)$ & $\begin{array}{l}\text { Cloud cover } \\
(\%)\end{array}$ \\
\hline \multicolumn{8}{|c|}{ Planaltina/2015 } \\
\hline 1 & February 28,2015 & 54 & B7 & 24.2 & 79 & 2.4 & 60 \\
\hline 2 & March 14, 2015 & 68 & $\mathrm{~F} 1$ & 26.1 & 74 & 3.9 & 30 \\
\hline 3 & March 29, 2015 & 83 & F4 & 24.9 & 61 & 1.9 & 45 \\
\hline 4 & April 13,2015 & 98 & $\mathrm{FC}$ & 24.6 & 73 & 1.4 & 60 \\
\hline 5 & April 27, 2015 & 112 & $\mathrm{C} 2$ & 26.1 & 59 & 2.0 & 50 \\
\hline 6 & May 12, 2015 & 127 & $\mathrm{C} 4$ & 19.0 & 92 & 1.8 & 15 \\
\hline \multicolumn{8}{|c|}{ Cristalina/2015 } \\
\hline 1 & February 20,2015 & 46 & B6 & 25.0 & 71 & 2.2 & 30 \\
\hline 2 & March 06, 2015 & 60 & $\mathrm{~F} 1$ & 24.6 & 66 & 1.5 & 60 \\
\hline 3 & March 21, 2015 & 75 & F3 & 24.4 & 71 & 2.3 & 35 \\
\hline 4 & April 04, 2015 & 89 & F7 & 23.4 & 60 & 1.8 & 45 \\
\hline 5 & April 17, 2015 & 102 & $\mathrm{FC}$ & 27.2 & 80 & 2.0 & 75 \\
\hline 6 & May 01,2015 & 116 & $\mathrm{C} 3$ & 25.1 & 55 & 1.3 & 60 \\
\hline \multicolumn{8}{|c|}{ Planaltina/2017 } \\
\hline 1 & February 24, 2017 & 50 & B6 & 25.4 & 61 & 1.4 & 45 \\
\hline 2 & March 10, 2017 & 64 & F1 & 26.4 & 68 & 2.0 & 30 \\
\hline 3 & March 25, 2017 & 79 & F3 & 27.2 & 69 & 2.1 & 5 \\
\hline 4 & April 08, 2017 & 93 & F5 & 26.1 & 76 & 2.6 & 5 \\
\hline 5 & April 21, 2017 & 106 & $\mathrm{C} 1$ & 25.4 & 78 & 0.5 & 90 \\
\hline 6 & May 06, 2017 & 121 & $\mathrm{C} 4$ & 25.3 & 59 & 3.6 & 5 \\
\hline
\end{tabular}

*The data were obtained by a thermo-hygro-portable digital anemometer during treatment application.

Ramularia leaf spot severity assessments were performed using the scale proposed by Aquino et al. (2008) (Figure 2) and based on the two central rows, considering all the plants within the useful area of each experimental plot. The assigned severity score represents the mean value for all evaluated plants. The evaluations were performed prior to each application of fungicide treatment and at 7, 14 and 21 days after the sixth application, resulting in a total of nine evaluations for each experiment. Based on the disease severity assessments, area under disease progress curve (AUDPC) was calculated.

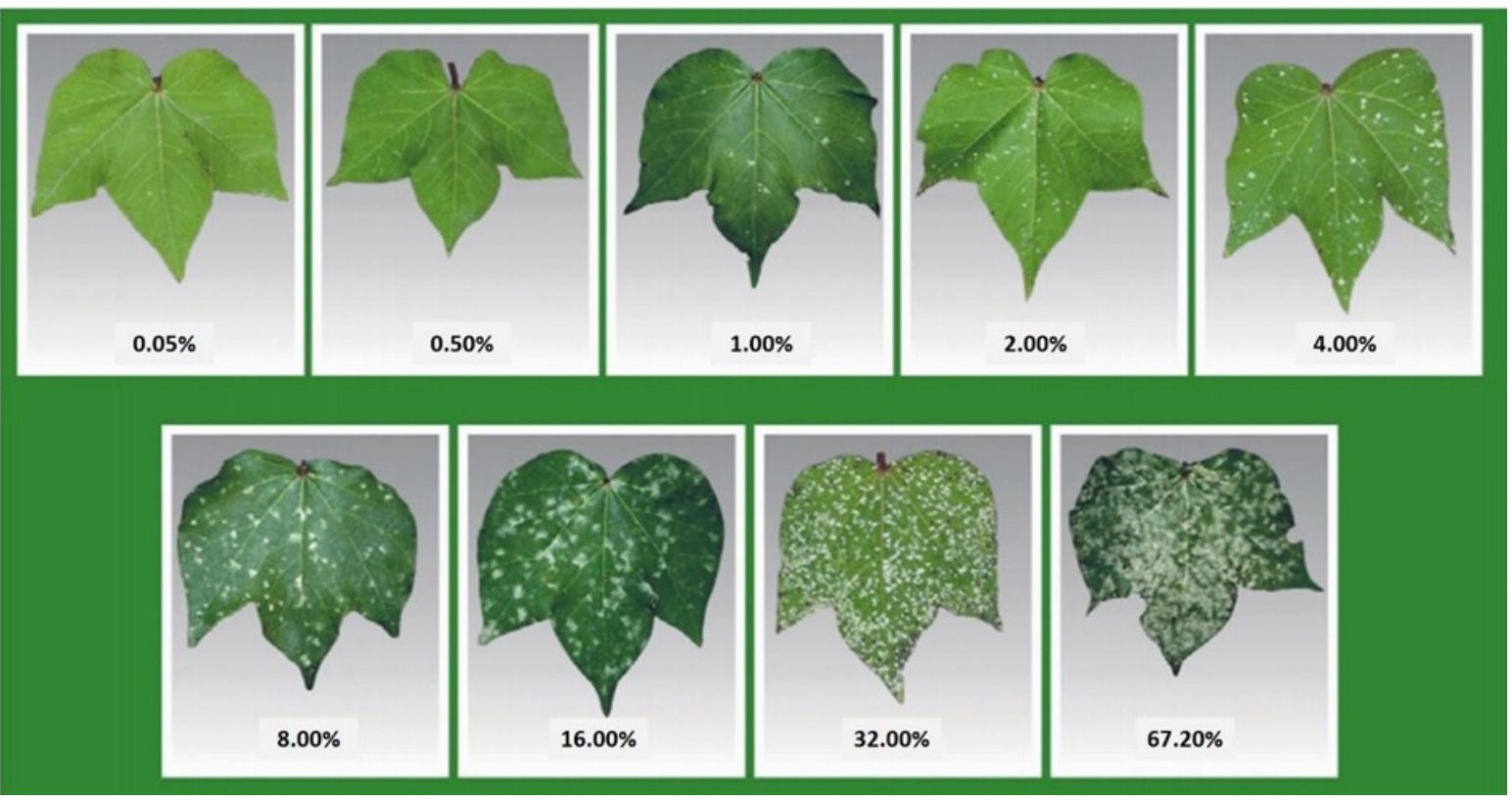

Figure 2. Diagrammatic scale (AQUINO et al., 2008) used to evaluate the ramularia leaf spot severity on cotton subjected to fungicide treatment.

Rev. Caatinga, Mossoró, v. 32, n. 3, p. 634 - 646, jul. - set., 2019 
The cotton yield was estimated by manual harvesting of all the bolls in the useful area of each experimental plot, composed of the two rows and four meters long $\left(6.08 \mathrm{~m}^{2}\right)$. Subsequently, the material obtained was weighed and the values were expressed in $\mathrm{kg} \mathrm{ha}^{-1}$. From the material harvested and weighed, 20 bolls per experimental plot were randomly selected to perform fiber quality analysis. These bolls were packed in paper bags and later the fiber was separated from the seeds.

After the beneficiation process, the fibers obtained were sent to the Association of Cotton Producers of Goiás (AGOPA) fiber analysis laboratory, which carried out the fiber technological characteristics analysis using an HVI (High Volume Instrument) apparatus. Among the variables obtained through the analysis, micronaire, length, strength and fiber uniformity were selected for analysis purposes in this work. The micronaire is admensional and is determined by the complex that involves the fiber fineness and maturity. The length is expressed in millimeters and represents the fibers average length as a proportion. Strength measurements reflect fiber tenacity or resistance to rupture, and are expressed in grams-force per tex $\left(\mathrm{gf} \mathrm{tex}^{-1}\right)$. The length uniformity is expressed as a percentage and establishes a relation between the average length and the average length of the longest fibers.

Experimental design, applied treatments and methodology were the same in the three experiments conducted in Planaltina/2015, Cristalina/2015 and Planaltina/2017. Based on these assumptions and considering that the relationship between the largest and the smallest residual mean square of the experiments was not discrepant, the data were submitted to joint analysis. According to Pimentel Gomes (1976) the relation between the residual average squares should be less than $4: 1$ to allow the joint analysis; Banzatto and Kronka (2006) stated this relation should not exceed the ratio 7:1. The mean residual squares were calculated for the variables AUDPC, cotton yield, micronaire, length, strength and fiber uniformity (Table 4).

Statistical analysis of data was performed using AgroEstat statistical software (BARBOSA; MALDONADO, 2015) and the graphs and regressions were generated in SigmaPlot software version 10.0 for Windows.

Table 4. Residual Averages Squares (RSS) obtained for the variables AUDPC, yield, micronaire, length, strength and uniformity of the cotton fiber and the relationship between the highest and lowest RSS for each variable.

\begin{tabular}{ccccc}
\hline \multirow{2}{*}{ Parameter } & \multicolumn{3}{c}{ Residual Sum of Squares (RSS) } & \multirow{2}{*}{$\begin{array}{c}\text { Higher QMr/ } \\
\text { Lowest QMr }\end{array}$} \\
\cline { 2 - 4 } & Planaltina/2015 & Cristalina/2015 & Planaltina/2017 & 2.74 \\
AUDPC & 2160.5 & 787.5 & 935.7 & 2.49 \\
Productivity & 58224.1 & 52803.9 & 131392.5 & 2.97 \\
Micronaire & 0.0484 & 0.0166 & 0.0163 & 2.63 \\
Length & 0.3636 & 0.1384 & 0.2013 & 2.20 \\
Strength & 0.4530 & 0.3217 & 0.7074 & 1.46 \\
Uniformity & 0.5172 & 0.3704 & 0.5398 & \\
\hline
\end{tabular}

Since requirements were satisfied to allow the three experiments joint analysis, AUDPC and yield data were submitted to joint analysis and the means obtained were compared by the Skott Knott test ( $\mathrm{p}$ $<0.05$ ). The variables of fiber technological characteristics, which determine its quality (micronaire, length, strength and uniformity), were submitted to regression analysis in relation to the AUDPC variable. The data were adjusted to the linear regression model " $y=a+b x "$, where " $y "$ is the quality variable, " $a$ " the intercept, " $b$ " the angular coefficient and " $x$ " the AUDPC.

\section{RESULTS AND DISCUSSION}

The environmental conditions in the three experiments were favorable to cotton development, which together with the cultivars' susceptibility and the inoculum availability in the areas favored increased RLS severity. The disease occurred in all three experiments and with high severity, providing a good opportunity to evaluate the fungicide treatment efficiency.

AUDPC, yield, micronaire, length, strength and fiber uniformity variables were significantly affected by both fungicide application and experiment location, as a result of RLS control differences. There was a significant interaction between fungicide application and experiments with respect to cotton yield only (Table 5). 
Table 5. P-value obtained from variance analysis for each variable studied.

\begin{tabular}{|c|c|c|c|c|c|c|c|}
\hline Cause variations & $\mathrm{DF}$ & $-\overline{A U D P C}$ & Yield & $\begin{array}{c}\mathrm{p}-\mathrm{v} \\
\overline{-} \\
\text { Micronaire }\end{array}$ & Length & Strength & $\overline{\text { Uniformity }}$ \\
\hline Blocks & 9 & 0.4368 & $<0.0001 *$ & 0.7370 & 0.6526 & 0.0693 & 0.3480 \\
\hline Treatments (T) & 16 & $<0.0001^{*}$ & $<0.0001 *$ & $0.0028 *$ & $0.0003^{*}$ & $<0.0001^{*}$ & $0.0018^{*}$ \\
\hline Experiments (E) & 2 & $<0.0001^{*}$ & $<0.0001 *$ & $<0.0001^{*}$ & $<0.0001 *$ & $<0.0001 *$ & $<0.0001^{*}$ \\
\hline Interaction $\mathrm{T} x \mathrm{E}$ & 32 & 0.0642 & $<0.0001 *$ & 0.5324 & 0.6421 & 0.9999 & 0.9433 \\
\hline Residue & 144 & - & - & - & - & - & - \\
\hline Total & 203 & - & - & - & - & - & - \\
\hline
\end{tabular}

*Statistically significant $(\mathrm{p}<0.05)$; DF-degrees of freedom.

AUDPC was affected by both fungicide and site of experiment, however there was no interaction between these two factors. This result indicates that the fungicide behavior was similar in the three experiments evaluated. RLS was significantly reduced due to fungicide application, independent of the fungicide, compared to the control treatment (Figure 3).

QoI fungicides, represented in this work by the active ingredients azoxystrobin, pyraclostrobin and picoxystrobin, were similar to each other and obtained the lowest control efficiency among all tested fungicides. These results indicate that these fungicides should not be applied alone to control the RLS. In addition, the existence of $R$. gossypii isolates with low sensitivity to QoI fungicides has previously been demonstrated (FRAC, 2012).

DMI fungicides, represented by difenoconazole, epoxiconazole, tetraconazole and metconazole, showed statistically superior performance to the strobilurin group and were comparable to some fungicides with the formulated mixture of QoI + DMI, such as azoxystrobin + difenoconazole and pyraclostrobin + metconazole. Despite the low efficiency of the QoI fungicides, its association with DMI is positive, since the application of DMI alone should be avoided due to the risk of selection of $R$. gossipy populations resistant to this group (ISHII; HOLLOMON, 2015). The highest efficiency was obtained by the application of fentin hydroxide and was statistically similar to pyraclostrobin + epoxiconazole + fluxapiroxade, pyraclostrobin + fluxapiroxade and azoxystrobin + tetraconazole. Considering the fact that fluxapiroxad is a SDHI (Succinate dehydrogenase inhibitor) fungicide, the results evidenced the existence of at least three chemical groups of fungicides (DMI, SDHI and inhibitors of oxidative phosphorylation) with good disease control efficiency.

Similar studies were conducted to verify the fungicide efficiency against the RLS in different regions of Brazil. Lopes et al. (2017) verified that fentin hydroxide more efficiently controlled RLS in Mato Grosso, compared to trifloxystrobin + prothioconazole and difenoconazole. These results agree with those obtained by Andrade Junior and Galbieri (2016), who evaluated the efficiency of different fungicides in the municipalities of Campo Verde and Sorriso in the state of Mato Grosso. The study showed that fentin hydroxide reduced the disease severity at both sites by 90.5 and $80.6 \%$, respectively. In the same work, the authors also highlight the effectiveness of the fungicides pyraclostrobin + fluxapyroxad, azoxystrobin + difenoconazole and difenoconazole. Silva, Suassuna and Bettiol (2017) reported that tetraconazole was efficient in reducing the disease severity in Mato Grosso, Bahia and Goiás. 


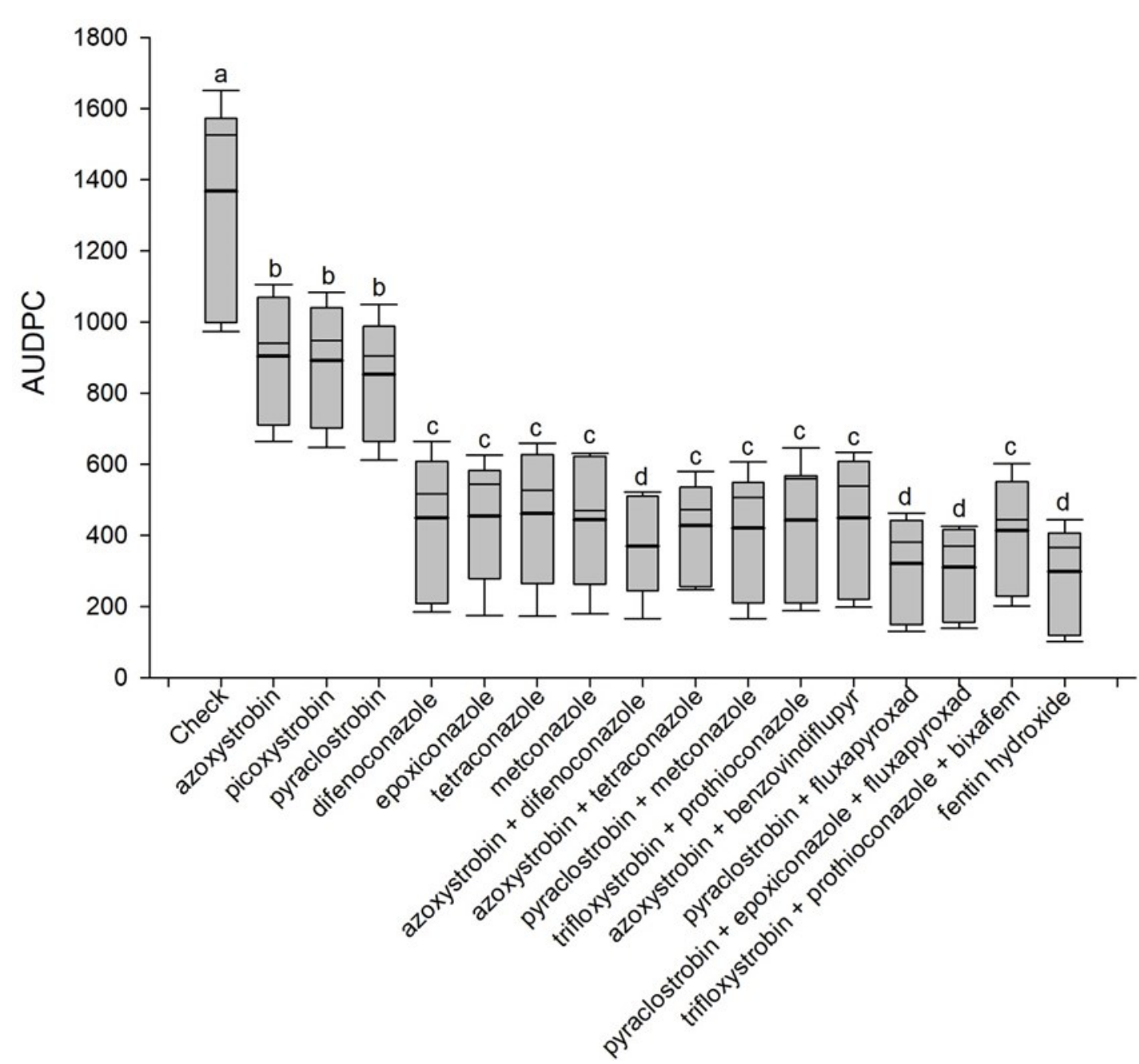

Figure 3. Area under the disease progress curve (AUDPC) in a cotton plant undergoing treatment with fungicides. The box plot represents results obtained in three experiments, conducted in Planaltina DF and Cristalina GO, during the 2014-2015 and 2016-2017 seasons. Bars followed by the same letter do not differ by Scott Knott's test $(\mathrm{p}<0.05)$.

Although the sites, years and the cultivars used in the above experiments are different from present work, there are consistencies in the results. For example, high efficiency was repeatedly observed for fungicides fentin hydroxide and pyraclostrobin + fluxapyroxad. These results are important, since they can be used as a basis for decision making, especially in years or situations where RLS exhibits very high severity.

RLS was the mainly responsible for the variations in cotton yield (Figure 4). Adjusted regressions have shown that there is a negative relationship between AUDPC and cotton yield, with decreasing yield as the AUDPC increases. There was a reduction of $0.85 \mathrm{~kg} \mathrm{ha}^{-1}$ for each increase point in AUDPC. The determination coefficients obtained indicate that approximately $69 \%$ of the variation in yield can be explained by variations in the AUDPC.

Cotton yield was affected by fungicides and the sites of experiments. Furthermore, there was an interaction between these factors. The reduction in yield resulting from fungicide treatment was from $9 \%$ to $59 \%$ considering each experiment isolated and, on average, resulted in a reduction of $15 \%$ to $32 \%$ (Figure 4). This highlights the potential for disease damage to cotton yield in untreated plants. 


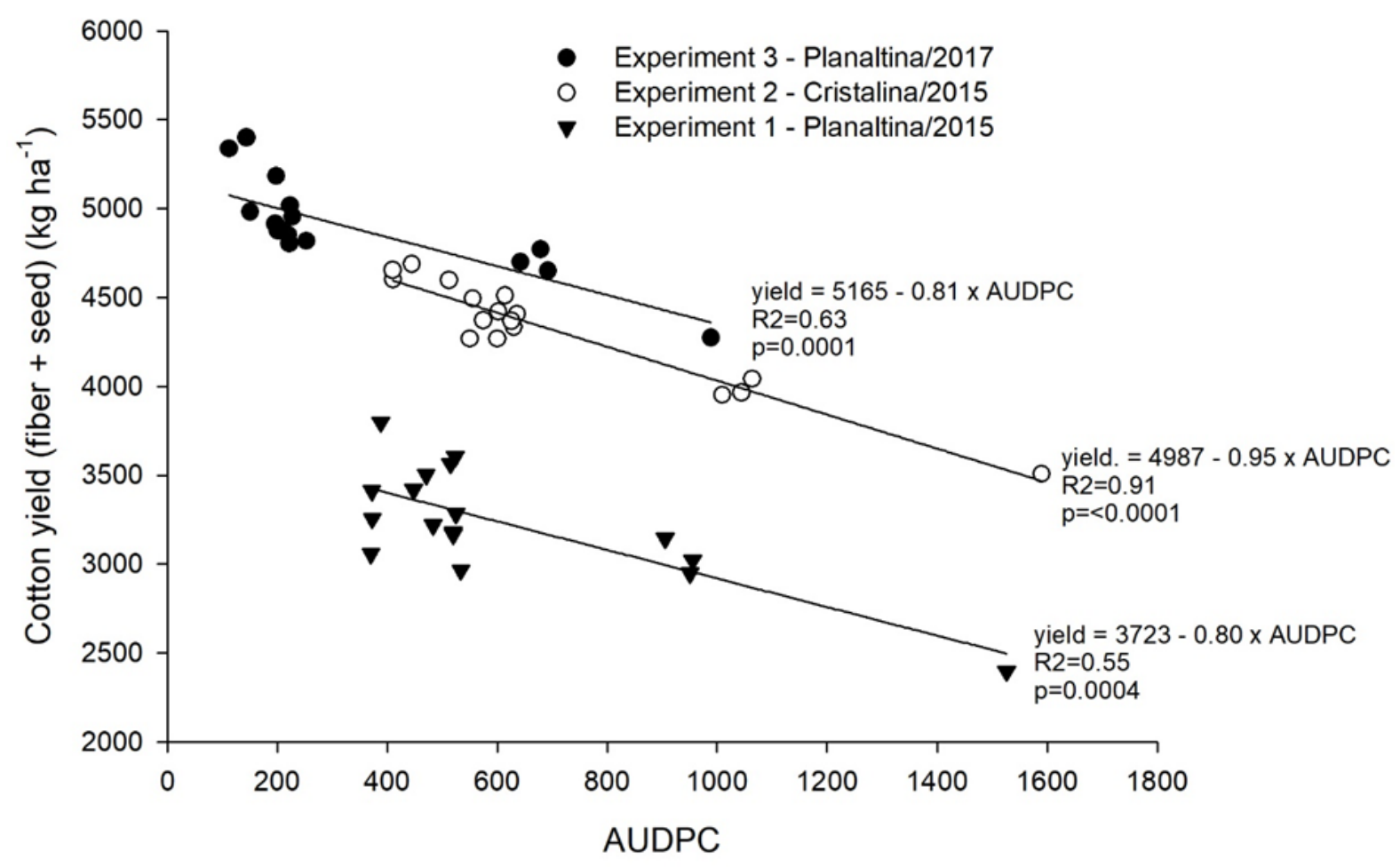

Figure 4. Relation between area under the disease progress curve (AUDPC) and cotton yield in Planaltina/2015, Cristali$\mathrm{na} / 2015$ and Planaltina/2017.

Gilio et al. (2017) obtained yield reductions varying from $19.86 \%$ and $38.83 \%$ in resistant and susceptible cultivars, respectively, due to RLS disease. Dias and Theodoro (2017), evaluated the efficiency of different control programs on RLS in the cultivars FMT 701, FMT 705 and FMT 709, and found yield variations in relation to the control treatment of up to $27.2 \%$. Andrade Junior and Galbieri (2016), reported that the fungicides that provided better control of RLS also obtained the highest yield, with increases varying from 886 . $\mathrm{kg} \mathrm{ha}^{-1}$ to $964.5 \mathrm{~kg} \mathrm{ha}^{-1}$ compared to the untreated treatment. The treatments with fungicide application achieved higher yields compared to the untreated for all the experiments. Among the fungicides evaluated, those belonging to the QoI group provided the smallest increases in yield $(15.2 \%)$. The other fungicides were statistically similar, providing an average increase of $25.7 \%$ in productivity in relation to the control treatment (Figure 5).

The increases obtained in cotton yield as a result of RLS control justify in part the large number of fungicide applications that have been carried out in the crop. In this work, there was an average gain of $805 \mathrm{~kg} \mathrm{ha}^{-1}$ in cotton yield, which would result in monetary gains that surpass fungicide application costs.

However, it would be more beneficial to use technical criteria necessary to obtain high efficiency and reduced environmental impacts. The use of more efficient products based on well-defined technical criteria can result in fewer applications, reduced costs and reduced environmental impacts, without necessarily compromising control efficiency and yield.

Variables micronaire, length, strength and fiber uniformity were significantly affected by treatments and experiments, but there was no interaction between these factors. The adjusted regressions between AUDPC and fiber quality variables showed that most of the variations observed were due to disease gradients obtained in response to fungicide application. 


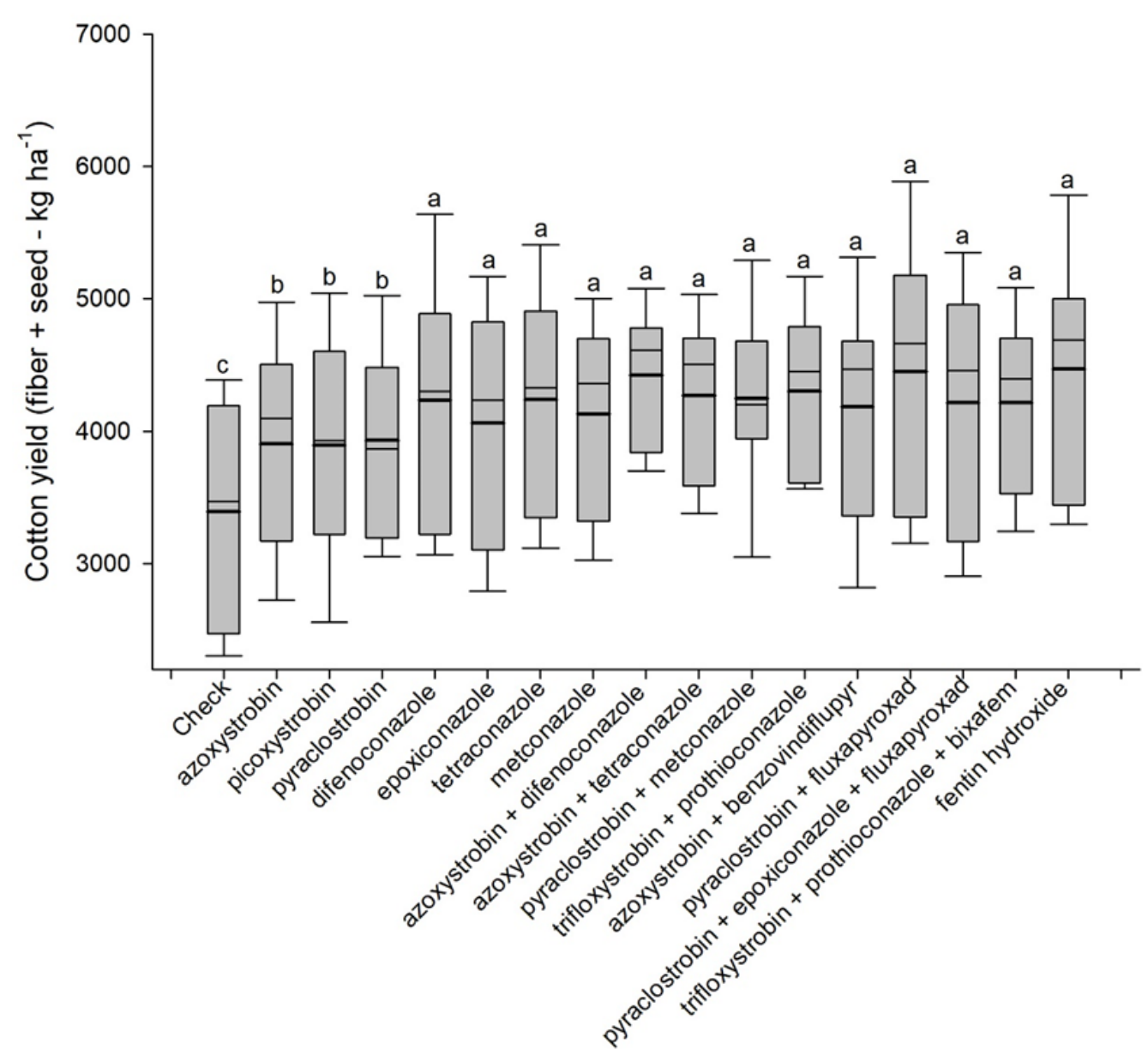

Figure 5. Cotton yield subjected to fungicide treatment in experiments in the 2015 and 2017 crops in Goiás. *Data represents the three experiments average.

The linear equation model $(y=a+b x)$ was adequate for the data obtained and the fit was significant for all variables in the three experiments, as can be observed in Table 6 . The determination coefficients obtained indicate that more than half of the variations observed in the variables micronaire, length, strength and fiber uniformity were explained by the variations in AUDPC.

Table 6. Summary of the statistical analysis and the regression model used to study the relationship between the area under the disease progress curve of the ramularia spot (AUDPC) and the variables of fiber quality micronaire, length, strength and uniformity in three chemical control experiments of cotton swelling.

\begin{tabular}{ccccccc}
\hline \multicolumn{7}{c}{ Model summary } \\
\hline Test site & Variable & $\mathrm{p}$-value & $\mathrm{R}^{2}$ & $\mathrm{R}^{2}$ adjusted & Standard error & Durbin-Watson \\
\hline \multirow{2}{*}{$\begin{array}{c}\text { Planaltina } \\
2015\end{array}$} & Length & 0.0074 & 0.4230 & 0.3845 & 0.1751 & 2.2250 \\
& Strength & 0.0147 & 0.3693 & 0.3273 & 0.2579 & 2.2838 \\
& Uniformity & 0.0002 & 0.3303 & 0.2857 & 0.3791 & 1.7180 \\
\hline \multirow{2}{*}{ Cristalina } & Micronaire & 0.0003 & 0.6426 & 0.6187 & 0.0914 & 2.5307 \\
& Length & $<0.0001$ & 0.7617 & 0.7458 & 0.1135 & 1.0433 \\
& Strength & $<0.0001$ & 0.6789 & 0.6575 & 0.1783 & 2.2280 \\
\hline \multirow{2}{*}{ Planaltina } & Uniformity & 0.02 & 0.6779 & 0.6565 & 0.1421 & 2.0179 \\
& Micronaire & 0.0006 & 0.5021 & 0.4689 & 0.0770 & 1.7374 \\
& Length & $<0.0001$ & 0.6546 & 0.6316 & 0.2868 & 2.0349 \\
& Strength & $<0.0001$ & 0.7549 & 0.7386 & 0.2015 & 2.1460 \\
\hline
\end{tabular}


Angular coefficients of the equations were higher in the experiments with higher AUDPC (Planaltina/2015 and Cristalina/2015), showing that the disease effect on the variables of fiber quality varies according to disease intensity (Figure 6). The higher the angular coefficient, the greater the slope of a line and consequently the greater the impact on a dependent variable $\mathrm{y}$ as an independent variable $x$ is changed.

Based in the angular coefficient, it can be inferred that the micronaire was less affected by
AUDPC than the other variables, since it presented the lowest angular coefficients in the three experiments. The fiber strength variable was the most affected by AUDCP, and, length and uniformity, showed intermediate behavior and with greater variation between the experiments.

In this work, the data obtained consistently demonstrated that the increase in disease severity, in this case represented by AUDPC, caused a reduction in cotton fiber quality variables micronaire, length, strength and strength uniformity.

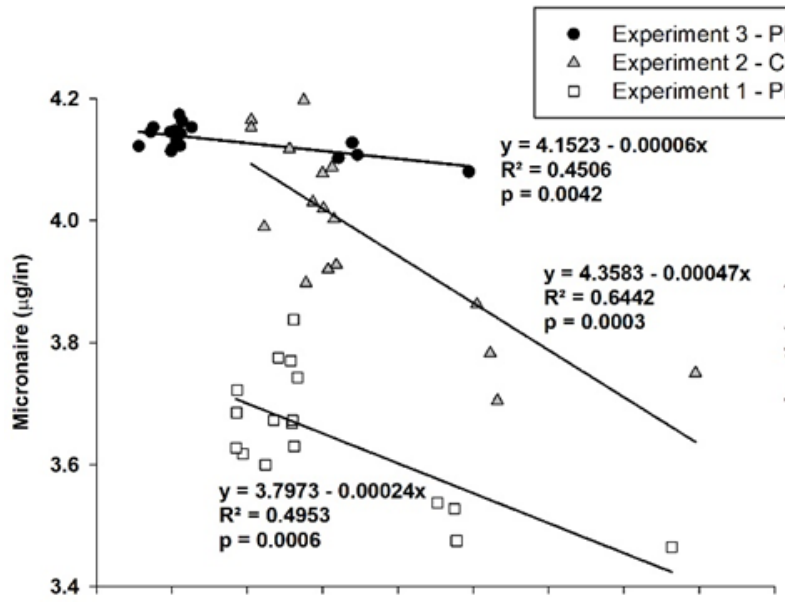

analtina/2017

lanaltina/2015
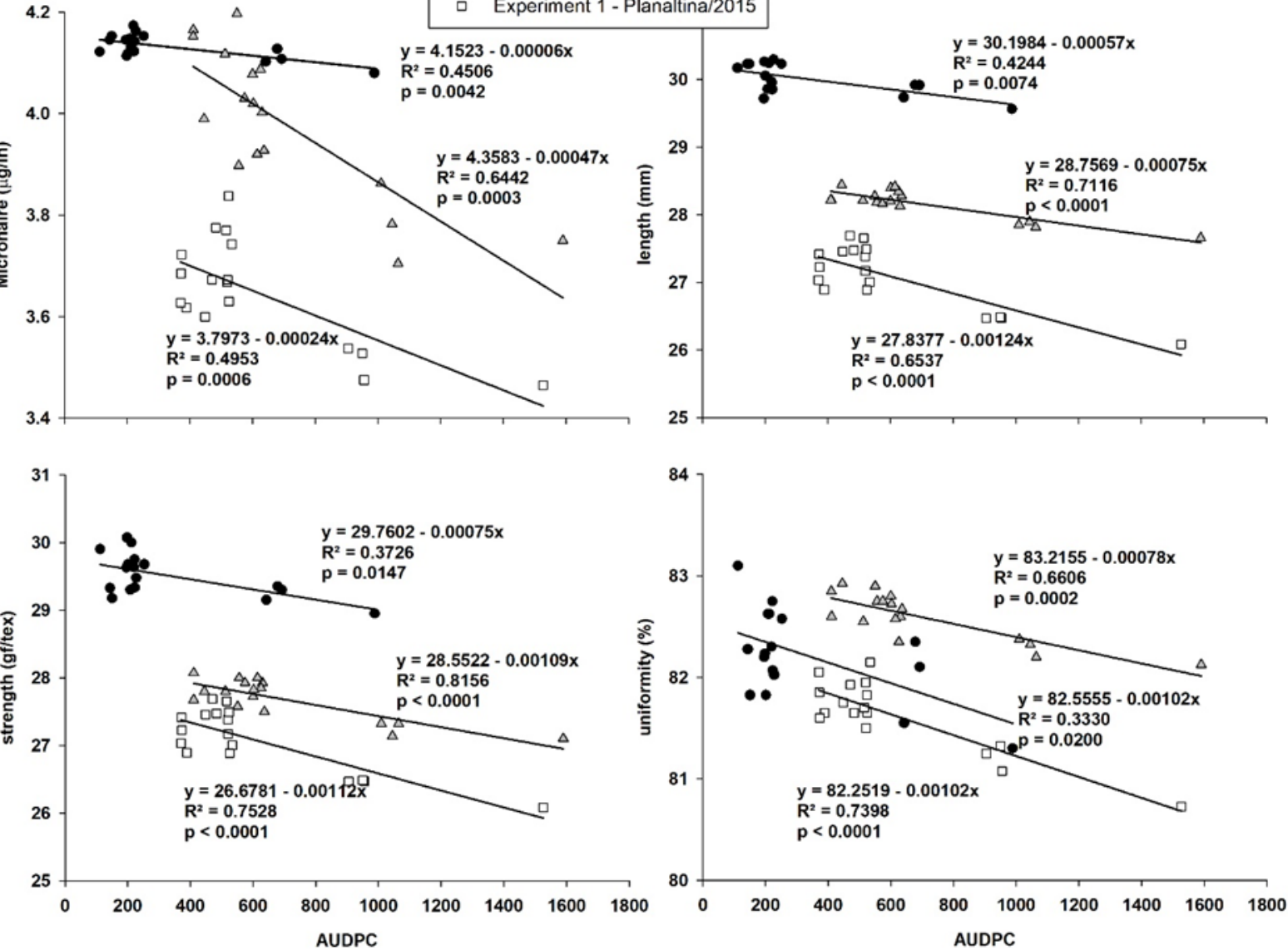

Figure 6. Relation between the area under the disease progress curve of the ramularia leaf spot (AUDPC) and the variables micronaire, length, strength and the cotton fiber uniformity in experiments of ramularia leaf spot control conducted in Planaltina/2015, Cristalina/2015 and Planaltina/2017.

The authors Dias and Theodoro (2017), studied the relationship between fiber quality and the cotton RLS occurrence and found that there was a reduction in fiber micronaire in plots not treated with fungicide due to the RLS occurrence. Silva (2014) concluded that Trichoderma harzianum and Trichoderma asperellum did not affect the strength, length and micronaire, nor did they affect the RLS severity. Gilio et al. (2017) observed that the RLS negatively affects fiber strength but has no effect on micronaire, uniformity and length.

According to Freire (2015), final quality depends on several intrinsic and extrinsic factors, including genetics (cultivar), abiotic factors (temperature, relative humidity, solar radiation) and biotic factors (diseases, pests, invasive plants). Specifically, in relation to diseases, it is known that RLS high severity causes defoliation in the lower branches and accelerates the process of opening bolls, compromising productivity and affecting fiber quality (SUASSUNA; COUTINHO, 2007).

In addition, it is known that cotton fiber consists mainly of cellulose, which represents $90 \%$ of its dry weight, and moisture, pectins, gum, grease and organic matter. However, the initial content of cellulose is low, and the process of fiber formation is long, starting in pre-anthesis and extending for up to 50-70 days (BELTRÃO et al., 2008; SESTREN; 
LIMA, 2015). As a carbohydrate, the cellulose deposition process depends directly on the plant photosynthetic capacity, which is affected by RLS

\section{CONCLUSIONS}

All the evaluated fungicides significantly reduced the AUDPC in relation to the control treatment and induced higher cotton yield. Fungicides belonging to the QoI chemical group demonstrated the least efficient control of disease when applied alone.

RLS was the main factor responsible for the variations in cotton yield, and produced damages that ranged from $14.8 \%$ to $31.7 \%$. The disease reduced cotton fiber quality, causing a negative impact on the technological characteristics of fiber micronaire, length, strength and uniformity.

\section{ACKNOWLEDGEMENTS}

This work was supported by CNPq, CAPES and Phytus Group.

\section{REFERENCES}

ANDRADE JUNIOR, E. R.; GALBIERI, R. Eficiência de fungicidas no controle da mancha de ramulária em algodoeiro na safra 2015/16 em Mato Grosso. Cuiabá, MT: IMA-MT, 2016. 8 p. (Circular técnica n²6/2016).

AQUINO, L. A. et al. Elaboração e validação de escala diagramática para quantificação da mancha de ramulária do algodoeiro. Summa Phytopathologica, v. 34, n. 4, p. 361-363, 2008.

BANZATTO, D. A.; KRONKA, S. N. Experimentação agrícola. 4. ed. Jaboticabal, SP: FUNEP/ UNESP, 2006. 237 p.

BARBOSA, J. C.; MALDONADO JÚNIOR, W. Experimentação Agronômica e Agroestat Sistema para análises estatísticas de ensaios agronômicos. Jaboticabal, SP: Multipress, 2015. $396 \mathrm{p}$.

BELTRÃO, N. E. M. et al. Fisiologia da fibra do algodoeiro herbáceo. In: BELTRÃO, N. E. M.; AZEVEDO, D. M. P. (Eds.). O agronegócio do algodão no Brasil. Brasília: Embrapa Informação Tecnológica, 2008. v. 2, cap. 32 p. 1121-1138.

CHITARRA, L. G. et al. Controle químico da mancha de ramulária do algodoeiro, causada por Ramularia areola, em função da idade da planta e occurrence (CURVÊLO et al., 2013).

da severidade da doença: safra 2003/2004. Campina Grande, PB: Embrapa Algodão, 2005. 16 p.

CIA, E. et al. Reação de genótipos de algodoeiro à incidência da mancha de ramularia em condições naturais de infestação. In: CONGRESSO BRASILEIRO DO ALGODÃO, 7., 2009, Foz do Iguaçu. Anais... Campina Grande: Embrapa Algodão, 2009. 1 CD-ROM.

CURVÊLO, C. R. S. et al. Mecanismos bioquímicos da defesa do algodoeiro à mancha de ramulária mediados pelo silício. Bragantia, v. 72 , n. 1, p. 41 51, 2013.

DIAS, A. R.; THEODORO, G. F. Integração de cultivares resistentes e fungicidas no controle da mancha de ramulária (Ramularia areola) e produtividade do algodoeiro. Revista de Ciências Agroveterinárias, v. 16, n. 3, p. 221-230, 2017.

FUNGICIDE RESISTANCE ACTION COMMITTEE - FRAC. List of plant pathogenic organisms resistant to disease control agents. Disponível em: < http://www.frac.info/docs/defaultsource/working-groups/sdhi-fungicides/group/list-ofresistant-plant-pathogens_2012-edition.pdf? sfvrsn=ef18469a_2>. Acesso em 20 fev. 2019.

FREIRE, E. C. Algodão no Cerrado. 3. ed. Brasília, DF: Positiva, 2015. 956 p.

GILIO, T. A. S. et al. Estimated damage caused by ramularia leaf spots on cotton. African Journal of Agricultural Research, v. 12, n. 1, p. 12-19, 2017.

IAMAMOTO, M. M. Doenças foliares do algodoeiro. 1. ed. Jaboticabal, SP: Funep, 2003. 41 p.

ISHII, H.; HOLLOMON, D. W. Fungicide resistance in plant pathogens: principles and a guide to practical management. Tokyo: Spriger, 2015. 489 p.

KLEFFMANN GROUP. GB Cereals Crop Protection Preliminary Amis Results 2014-2015. Kleffmann Group, 2015.

LOPES, L. O. et al. Efeito de fungicidas para o controle da Ramularia areola na cultura do algodoeiro. Summa Phytopathologica, v. 43, n. 3, p. 229-235, 2017.

MEHTA, Y. et al. Mycosphaerella areola-The Teleomorph of Ramularia areola of Cotton in Brazil, and Its Epidemiological Significance. American Journal of Plant Sciences, v. 7, n. 10, p. 1415-1422, 2016. 
NOVAES, T. G. et al. Herança de resistência do algodoeiro a Ramularia areola. Summa Phytopathologica, v. 37, n. 2, p. 150-152, 2011.

PAIVA F. A. Doenças. In: EMBRAPA AGROPECUÁRIA DO OESTE (Eds.). Algodão: tecnologia de produção. Dourados: Embrapa Agropecuária Oeste, 2001. cap. 13, p. 245-266.

PIMENTEL GOMES, F. Curso de estatística experimental. 6. ed. Piracicaba, SP: Nobel, 1976. $430 \mathrm{p}$.

RATHAIAH, Y. Spore germination and mode of cotton infection by Ramularia areola. Phytopathology, v. 67, n. 3, p. 351-357, 1977.

ROCHA, C. L.; CARVALHO, C. L.; OLIVEIRA, C. G. Avaliação de fungicidas no controle de ramulária (Ramularia aerola) na cultura do algodão. In: XXXVIII CONGRESSO BRASILEIRO DE FITOPATOLOGIA, 2005, Brasília. Anais... Brasília: Fitopatologia Brasileira, v. 30, p. 582.

SESTREN, J. A.; LIMA, J. J. Características e classificação da fibra do algodão. In: FREIRE, E. C. (Ed.) Algodão no cerrado do Brasil. Brasília: Positiva, 2015. cap. 18, p. 653-749.

SILVA, J. C. D. Mancha de ramulária do algodoeiro: agente etiológico, produção de inóculo, resistência de genótipos e controle integrado. 2014. 45 f. Tese (Doutorado em Agronomia: Área de Concentração em Proteção de plantas) - Universidade Estadual Paulista "Júlio de Mesquita Filho, Botucatu, 2014.

SILVA, J. C.; SUASSUNA, N. D.; BETTIOL, W. Management of ramularia leaf spot on cotton using integrated control with genotypes, a fungicide and Tricho-derma asperellum. Crop Protection, v. 94, n. 1, p. 28-32, 2017.

SUASSUNA, N. D.; COUTINHO, W. M. Manejo das principais doenças do algodoeiro no cerrado brasileiro. In: FREIRE, E. C (Ed.). Algodão no cerrado do Brasil. Brasília: Talento, 2007. cap. 13, p. 479-521.

SUASSUNA, N. D. et al. Manejo de doenças do algodoeiro. In: BELTRÃO, N. E. M.; AZEVEDO, D. M. P. (Eds.). O agronegócio do algodão no Brasil. Brasília: Embrapa Informação Tecnológica, 2008. v. 2, cap. 29, p. 983-1032.

ZANDONÁ, C. et al. Mechanism of resistance and presence of different resistance genes to Ramularia areola in two cotton genotypes. Tropical Plant Pathology, v. 37, n. 3, p. 175-178, 2012. 